\title{
Reduction of odorous compounds emissions from swine slurry by electrolytic treatments and copper addition
}

\author{
Mauro Podrecca, Alessandro Chiumenti, Francesco Da Borso, Marco Contin, Maria De Nobili \\ Department of Agricultural, Food, Environmental and Animal Sciences, University of Udine, Italy
}

\begin{abstract}
Swine livestock farms represent potential sources of emissions of gaseous compounds and odors in relation to slurry management, manure treatment, and particularly, storage. Electrolytic treatments of slurries were proposed to solve this pressing problem. Electrolytic treatment consists of the passage of a low electric current through the liquid phase of swine manure in storage basins determined by two or more electrodes with alternated polarisation. We investigated the mechanisms of odour reduction and evaluated the effects of current intensity and of anodically dissolved copper $\left(\mathrm{Cu}^{2+}\right)$ ions. Fresh swine slurry was subject to electrolytic treatment in a bench top experiment, at $25 \mathrm{~mA}$ and $75 \mathrm{~mA}$ for 32 days with either copper or graphite electrodes. Emissions of methane, hydrogen sulphide, and volatile fatty acids were measured. Effects of copper addition to fresh swine slurry were also monitored in a bench top scale trial. Reduction of emissions was found to be due to both current passage and copper dissolution. Reduction of foul emissions in graphite electrodes assays resulted lower than in copper electrodes assays, although the direct additions of $\mathrm{Cu}^{2+}$ ions had a much larger effect than could be predicted from the results of electrolytic treatments with copper electrodes, probably due to the greater uniformity in distribution in swine manure. A simple empiric odour threshold value normalised index, odour offensiveness index of slurries, was found to be effective in differentiating treatments.
\end{abstract}

Correspondence: Mauro Podrecca, Department of Agricultural, Food, Environmental and Animal Sciences (DI4A), University of Udine, via delle Scienze 206, 33100 Udine, Italy.

E-mail:mauropod@hotmail.com

Key words: Electrolytic treatment; manure treatment; copper ions; volatile fatty acids; odour; swine; slurry.

Acknowledgements: the authors would like to thank Penny Lazo for the professional and kind support for the proof reading and English language editing of the paper.

Received for publication: 5 February 2016.

Accepted for publication: 26 December 2016.

(C) Copyright M. Podrecca et al., 2017

Licensee PAGEPress, Italy

Journal of Agricultural Engineering 2017; XLVIII:546

doi:10.4081/jae.2017.546

This article is distributed under the terms of the Creative Commons Attribution Noncommercial License (by-nc 4.0) which permits any noncommercial use, distribution, and reproduction in any medium, provided the original author(s) and source are credited.

\section{Introduction}

Emissions of volatile compounds in livestock farming during slurry storage, processing, and land application generate several environmental problems: they represent a potential health risk for workers and animals (especially when manure is collected under slatted floors in animal housings) and the diffusion of foul odors, in particular, can represent a cause of concern of people living in the neighbourhoods (Jones, 1977; Shusterman, 1992; Persaud et al., 1996). Offensive odour emitted from manure is primarily a result of an incomplete anaerobic degradation of the organic matter, especially proteins and carbohydrates (Spolestra, 1979, 1980; Zhu, 2000; Rappert and Müller, 2005; Higgins et al., 2008). This incomplete degradation results in the production of foul smelling compounds that can be divided into four different chemical classes: i) volatile fatty acids (VFA), both branched or straight chain; ii) aromatic compounds (i.e., indoles and phenols); iii) nitrogencontaining compounds (i.e., ammonia and volatile amines); and iv) sulphur-containing compounds (i.e., hydrogen sulphide and mercaptanes) (Zhu, 2000; Varel and Miller, 2001; Rappert and Müller, 2005; Hanajima et al., 2010). Normally, the emission of VFA, especially those with chain length between 2 and 5 atoms of carbon, is a reliable indicator of foul odour (Zhu et al., 1999; Sheridan et al., 2003), in fact, there is a good correlation between their concentration in the air and the perception of bad smell (Barth et al., 1974; Leek et al., 2007). However, not all compounds contribute with the same intensity, as the human nose has widely different sensitivities towards unpleasant smelling substances. The minimum concentration required for the human detection of the odour of a substance is termed odour threshold value (OTV) (Rappert and Müller, 2005). The potential contribution of a substance to the odour of a mixture can be related to the human perception of that single substance, but synergic or masking effects may also occur. Five compounds are the most important volatile fatty acids in foul odors: acetic acid, propionic acid, butyric acid, isovaleric acid, and valeric acids (Yasuhara et al., 1984). High concentrations of acetic acid and propionic acid do not prominently contribute to foul odour perception (Zhu, 2000), whereas butyric acid, isovaleric acid, and valeric acid, which have OTV much, lower than acetic acid contribute greatly (Shigeta, 1976; Zhu et al., 1999; Sheridan et al., 2003).

A system for the electrolytic treatment of livestock effluents was experimented, developed, and presented at commercial scale in the 90's but with limited diffusion. Three types of electrodes can be used for the electrolytic treatment: copper electrodes, which are the most common, iron electrodes, and graphite electrodes matched with plates of chemical salts. A direct current is applied at the electrolytic equipment, so that electrodes of each pair work as cathode and as anode. At regular intervals the polarity of the electrodes is reversed to reduce the electrode passivation and to reduce the fluctuations of resistance of slurry (Skjelhaugen 
and Donantoni, 1988; Zanardini et al., 2002). An effective polarity reverse time is approximately $10 \mathrm{~min}$ (Ranalli et al., 1996) and direct current intensity between 0.5 and 1.5 Ampere (Skjelhaugen and Donantoni, 1988); potential difference (voltage) ranges between 1 and $5 \mathrm{~V}$, but it must be higher of the minimum interval of 1.5-2.5 V to gain metal dissolution from electrodes (Skjelhaugen and Donantoni, 1988). Electrodes commonly used have cylindrical shape (43 cm length, $2.5 \mathrm{~cm}$ diameter). Each unit can treat from $500 \mathrm{~m}^{3}$ to $700 \mathrm{~m}^{3}$ of slurry depending on its characteristics (Chiumenti et al., 1988); treatment cycles last between 4 and 6 months (Skjelhaugen and Donantoni, 1988). The treatment showed energy consumption of 2.5-3.5 Wh per cubic meter of treated effluent (Chiumenti et al., 1993).

Applications had limited diffusion at the time, due to a general lack of interest by farmers, as awareness of the problem arose only later. Moreover, the process had been patented by a company, which soon after abandoned the manure management sector.

Due to its potential economic advantages with respect to chemical treatments, this technique has received new attention by researchers (Bejan et al., 2007), but the technology involves various mechanisms, which have not been fully clarified.

Chiumenti et al. (1988) individuated the following actions of the electrolytic treatment: i) oligodynamic: the activity of microorganism in the manure is diminished because of the locking of sulphidrylic groups by the metal cations released in the solution. In particular, copper elicits fluidisation of cellular membranes, with lysis and formation of anomalous structures; ii) electric: the fermentative activity is reduced because of the passage of an electric current of relatively high intensity; iii) complexing: the dissolution of metallic salts or other compounds bind to foul smelling volatile molecules reducing this volatility; iv) antiflocculating: preventing the formation of thick caps that hinder oxygen diffusion.

Another possible mechanism involved is the anodic production of oxygen at the anode, which generates hydrogen peroxide and hydroxyl radicals during water electrolysis. The anodic generation of oxygen is itself toxic to strictly anaerobic bacteria; moreover, hydroxyl radicals that are formed at certain electrodes are highly destructive to living cells and capable of causing damage to the cell membrane and their eventual rupture (Bejan et al., 2007). Hydroxyl radicals give way to radical chain auto-oxidation of the organic constituents of hog manure, with the first formed radical intermediates further oxidised by the molecular oxygen that is simultaneously evolved at the anode (Bejan et al., 2005; Bejan et al., 2007).

A significant effect of the treatment is represented by a reduction with time of pathogens content (Chiumenti et al., 1988), without relevant reduction of the total microbiological population. On the contrary, the adenosine triphosphate (ATP) content increases perhaps due to current passage which cause an alteration in cell membrane chemiosmotic mechanisms; this fact influences the movement of nutrients and the phosphorylation reaction (Ranalli et al., 1996). Some microorganisms can indeed accept electrons from a cathode to produce ATP through electron chain carriers (Lovley, 2008; Rosenbaum et al., 2010).

Another important effect of the electrolytic treatment is the reduction of stratifications in the slurry: sediment layers on the bottom and crust on the top decrease, because of the stimulation of cellulosolitic flora and reduction of materials in suspension (Chiumenti et al., 1988). The electric field allows compounds to migrate continuously depending on particles charge: the reduction of molecular interactions favouring neutralisation and flocculation is enhanced.

Despite the cited advantages, the diffusion of this treatment has decreased in more recent years, but a better understanding of the mechanisms involved may contribute useful information to devise more advanced technological approaches to solve the pressing problem of improving air quality in the neighbourhoods of pig farms.

The aim of this work was to evaluate the relative and eventual synergic contribution of electric field application at different current intensities and oligodynamic plus complexing action of $\mathrm{Cu}^{2+}$ ions, to the reduction of foul odors emission through electrolytic treatments. A further aim was to develop a methodology allowing for the comparison of the results in terms of reduction of potential odour impact: direct detection of odour level by means of olfactometry, in fact, requires significant labour, is costly and complex. Hence, this study was intended to verify the possibility of evaluating the potential odour impact by a simplified procedure based on the direct detection of the emissions of volatile fatty acids.

\section{Materials and methods}

\section{Swine slurry origin and characteristics}

Fresh swine slurry was collected from a pig farm located near Udine (North-East Italy). The characteristics of the slurry were the following: total solids (TS) $2.8 \%$; volatile solids $58 \%$ on dry basis; density $1.015 \mathrm{~kg} \mathrm{~L}^{-1}$; chemical oxygen demand (COD) $20120 \pm 3240 \mathrm{mg} \mathrm{L}^{-1}$; total sulphide content $379 \pm 21 \mathrm{mg} \mathrm{L}^{-1}$.

Total solids were determined after heating homogenised samples at $105^{\circ} \mathrm{C}$ for $24 \mathrm{~h}$, volatile solids were measured on the dry residue by heating at $550^{\circ} \mathrm{C}$ for $12 \mathrm{~h}$ (APHA AWWA WPCF, 1992). Specific conductivity and $\mathrm{pH}$ were measured in surnatant solutions after centrifuging samples at $12,000 \mathrm{rpm}$ for $20 \mathrm{~min}$. Ammonia was measured potentiometrically by an ion selective probe on homogenised and diluted (1:10) samples. Sulphides were analysed on $5 \mathrm{~mL}$ sample aliquots by the iodometric method, by adding 10 $\mathrm{mL}$ of $0.025 \mathrm{~N}$ standardised iodine solution and $2 \mathrm{~mL}$ of $6 \mathrm{~N} \mathrm{HCl}$, samples were then titrated with $0.025 \mathrm{~N}$ thiosulphate. COD was determined with the American Public Health Association (APHA) method (APHA AWWA WPCF, 1992).

\section{Electrolytic cell processes}

Swine slurries were subjected for 32 days to four different treatments: two electrolytic treatments at two levels of constant current intensity were performed with either graphite or copper electrodes. A control treatment consisting in slurry incubation without current application was also performed under the same environmental conditions. Three separate replicates (4 L of slurry) were set up for each treatment for a total of 15 vessels.

Electrolysis was performed in bench top cells made of $5 \mathrm{~L}$ polypropylene vessels filled with $4 \mathrm{~L}$ of slurry. Electrolytic cell tests were carried out with either copper or graphite electrodes: reverse time of polarity between cathode and anode was $2 \mathrm{~min}$, and the intensity of current applied was 25 and $75 \mathrm{~mA}$. Electrodes were $30 \mathrm{~cm}$ long with $0.5 \mathrm{~cm}$ diameter and were placed at a distance 14 $\mathrm{cm}$ apart, $4 \mathrm{~cm}$ from the side of the vessel and $2 \mathrm{~cm}$ from the bottom. The cells were maintained in the open under a roof to protect them from the rain; the mean temperature was $12^{\circ} \mathrm{C}$ and varied during the course of the experiment between 10 add degrees after 10 and $15^{\circ} \mathrm{C}$.

\section{Emissions}

To minimise the effect of environmental conditions, in order to compare the effect of the various treatments, emissions were meas- 
ured under controlled laboratory conditions in thermostated $\left(20^{\circ} \mathrm{C}\right)$ closed containers. Slurry samples $(10 \mathrm{~mL}$ from each of the three independent replicates) were collected from treated slurries and from an untreated control every 8 days through a glass pipette immersed into the middle of the vessel and immediately transferred to separate $120 \mathrm{~mL}$ dark glass bottles with Teflon sept caps. Concentrations of methane, hydrogen sulphide, and VFA were measured in the headspace. Ammonia was trapped in $0.2 \mathrm{M}$ sulphuric acid.

Hourly emissions (E) were calculated as:

$$
E\left(\text { umoles } \cdot g^{-1} \cdot h^{-1}\right)=\frac{C \cdot V_{\text {gas }}}{w_{\text {sample }} \cdot t}
$$

where $\mathrm{C}$ is the concentration of gas in the headspace, $\mathrm{V}_{\text {gas }}$ is the void volume of the vial, $\mathrm{w}_{\text {sample }}$ is the dry weight of the sample, and $\mathrm{t}$ time in hours. Cumulative emissions were calculated from graphical interpolations.

\section{Copper addition treatment}

The effect of addition of copper ions at different concentrations in the absence of electrolytic treatments was examined in a laboratory experiment.

Different aliquots of a $0.1 \mathrm{M}$ stock solution of $\mathrm{CuCl}_{2}$ were added to freshly collected swine slurry at the rate of $0 \mathrm{mg}, 200 \mathrm{mg}$, $400 \mathrm{mg}, 800 \mathrm{mg}$ and $1200 \mathrm{mg} \mathrm{Cu}^{2+} \mathrm{kg}^{-1} \mathrm{TS}$, corresponding respectively to $1.25 * 10^{-4}, 2.5 * 10^{-4}, 5 * 10^{-4}$ and $7.5 * 10^{-4}$ moles L $\mathrm{L}^{-1}$ $\mathrm{Cu}^{2+}$. Each treatment, including control, had three separate replicates. The amount of copper added was in the range of $\mathrm{Cu}^{2+}$ concentrations encountered in electrolytic treatments (Chiumenti and Donantoni, 1991). Slurry samples (one from each of the three separate replicate treatments) were collected through a glass pipette and immediately transferred to dark glass bottles $(120 \mathrm{~mL})$ with PTFE/silicon septa for micro-syringe sampling of gases. Bottles (three replicates) filled with $12 \mathrm{~mL}$ of slurry (10\% volume) were closed, shaken, and incubated for 7 days at $20^{\circ} \mathrm{C}$. VFA, methane, and hydrogen sulphide concentrations were measured in the head space at the end of the incubation.

\section{Gas chromatographic analysis}

A HRGC MEGA 2 FISONS INSTRUMENTS 8560 GC was used with a FID detector (flame ionisation detector) set at $275^{\circ} \mathrm{C}$. The injector operated in splitless mode, ignited through an air and hydrogen mixture at $250^{\circ} \mathrm{C}$. A capillary AT- 1000 column (Supelco, Bellefonte, PA, USA) was used for analysing acetic acid, propionic acid, butyric acid, isobutyric acid, and valeric acid; the carrier gas was helium with the flow rate of $5 \mathrm{~mL} \mathrm{~min}{ }^{-1}$. Column temperature was initiated at $60^{\circ} \mathrm{C}$, with an increasing rate of $4^{\circ} \mathrm{C}$ per minute up to $112^{\circ} \mathrm{C}$ for a total time of $13 \mathrm{~min}$; volume injected was $100 \mu \mathrm{L}$.

To calculate the concentrations of VFA in the headspace of bottles, pure standards of each VFA (99.9\%) were used after a 1:200 dilution with diethyl ether in hermetic vials. The density (Merck index) of each VFA, the dilution and the amount of sample injected in the gas chromatograph $(1 \mu \mathrm{L})$ were used to calculate the individual response factors. For the analysis of methane and hydrogen sulphide, samples were handled in the identical way but incubated for $1 \mathrm{~h}$ at room temperature. A HRGC MEGA 2 CE/INSTRUMENTS 8540 gas chromatograph equipped with a thermal conductivity detector was used. Temperature was $110^{\circ} \mathrm{C}$ and $150^{\circ} \mathrm{C}$ for the filament and bridge, respectively. Column was a packed Poropak Q (ALTECH Srl, Bareggio, MI, USA) and helium at a flux of $20 \mathrm{~mL}$ $\mathrm{min}^{-1}$ as carrier gas, the initial temperature gradient was set at $50^{\circ} \mathrm{C}$ for $2 \mathrm{~min}$, then at $25^{\circ} \mathrm{C}$ per minute up to $100^{\circ} \mathrm{C}$, followed by a $5 \mathrm{~min}$ isotherm; volume injected was $200 \mu \mathrm{L}$. To calculate the methane proportion between chromatographic areas and the concentration in the samples, a pure standard (1\%) was injected (5 $\mathrm{mL}$ ) in a $120 \mathrm{~mL}$ bottle with PTFE/silicon septa and analysed. Hydrogen sulphide standard was obtained treating a known amount of sodium hydrate sulphide $\left(\mathrm{NaS}_{2}(7-9) \cdot \mathrm{H}_{2} \mathrm{O}\right)$ with sulphuric acid concentrated and in a $120 \mathrm{~mL}$ bottle with a PTFE/silicon septa screw cap, which was immediately closed for gas chromatograph analysis. The amount of sulphide $\left(18.6 \% \mathrm{w} / \mathrm{W} \mathrm{S}^{2-}\right)$ in the sodium hydrate; sulphide was determined through iodometric titration.

\section{Offensivity index}

In order to evaluate the effect of treatments on potential odour perception an empiric offensivity index (OI) derived from the odour threshold value (OTV) normalised contributions was devised. The index was calculated as the sum of the concentrations of VFA $\left(\mathrm{c}_{\mathrm{i}} ; \mu \mathrm{g} \mathrm{m}^{-3}\right)$ measured in the headspace of bottles per $\mathrm{g}$ of total dry solids, each divided by its relative $\operatorname{OTV}_{\mathrm{i}}\left(\mu \mathrm{g} \mathrm{m}^{-3}\right)$ :

$$
O I=\sum_{0}^{i}\left[\frac{c_{i}}{O T V_{i}}\right]
$$

$O T V_{i}$ values, are the lowest concentrations perceived by subjects and were taken from Ruth (1986).

\section{Statistical treatment}

Quantitative variables were characterised by the average value and standard deviation of three independent replicates. All measures were based on TS and expressed as mean \pm standard deviation. The non-parametric Kruskal-Wallis test was performed to examine the significance of difference between treatments $(\mathrm{P}<0.05)$. Data were statistically analysed by $\mathrm{R}$ software ( $\mathrm{R}$ Development Core Team, 2010).

\section{Results and discussion}

\section{Electrolytic treatments}

The lower current applied in the electrolytic treatments $(25 \mathrm{~mA}$ constant current) was chosen as the minimum applied current which enabled to obtain, with copper electrodes, a potential difference between 1.5 and $1.8 \mathrm{~V}$, a range sufficient to induce oxidation and dissolution of $\mathrm{Cu}^{2+}$ at the anode. With graphite electrodes, at $25 \mathrm{~mA}$, potential differences ranged between 3.0 and $3.5 \mathrm{~V}$ and were sufficient to precipitate water electrolysis resulting in anodic production of oxygen. The highest current $(75 \mathrm{~mA}$ constant current) was the highest current that enabled stable continuous operation under the established experimental conditions. In contrast to the control, no stratification and formation of crust was observed in all the electrolytic treatments. In the graphite electrodes treatments, the slurry became greenish and more fluid than the control.

\section{Chemical parameters}

As showed in Table 1, differences in $\mathrm{pH}$, which ranged between $\mathrm{pH}$ 7.4-8.2 throughout the experiment, were small and not likely to cause any impact on either production or release of unpleasant smells. The same occurred for specific conductivity 
which tended to decrease slightly in all treatments and increased again only at the end of the experiment, ranging between 28.9 and $35.5 \mathrm{mS} \mathrm{cm}-1$. Ammonia concentrations in the slurry tended to decrease with time, being insufficiently affected by treatments (0.36-0.49 $\mathrm{mol} \mathrm{L}^{-1}$ ) (Table 1). The $75 \mathrm{~mA}$ treatment with copper electrodes was the only treatment which caused the redox potential to increase from about $-400 \mathrm{mV}$ to $-133 \mathrm{mV}$ after 32 days; in the other treatments, redox potentials all remained very negative and typical of fully anaerobic conditions (Table 1).

\section{Emissions}

Hydrogen sulphide emission rates were not significantly reduced as compared to control in electrolytic treatments; however, cumulative emissions from electrolitically treated slurry were lower (Table 2). Methane emission rates were variable but always lower than control at $75 \mathrm{~mA}$ intensity, with either graphite or copper electrodes; at $25 \mathrm{~mA}$ intensity no significant differences were found between treatments and control. Cumulative emissions were, however, lower from electrolytically treated slurries (Table 2) even at $25 \mathrm{~mA}$ intensity.

Emissions of VFA were larger at the beginning of the experiment and then decreased to increase again at the last sampling for propionic, isobutyric, and valeric acids (Figure 1). Butyric acid emissions were largest at the end of the experiment and emissions

Table 1. Effects of electrolytic treatments at 25 and $75 \mathrm{~mA}$ on $\mathrm{pH}$, conductivity, redox potential and ammonia concentrations of swine slurry during 32 days of incubation. All values are the mean of three independent replicate determinations \pm standard deviations.

\begin{tabular}{|c|c|c|c|c|c|}
\hline & \multirow[t]{2}{*}{ Control } & \multicolumn{2}{|c|}{ Copper electrodes } & \multicolumn{2}{|c|}{ Graphite electrodes } \\
\hline & & $25 \mathrm{~mA}$ & $75 \mathrm{~mA}$ & $25 \mathrm{~mA}$ & $75 \mathrm{~mA}$ \\
\hline \multicolumn{6}{|l|}{$\mathrm{pH}$} \\
\hline day 1 & $7.1 \pm 0.2^{\mathrm{a}}$ & $7.1 \pm 0.2^{\mathrm{a}}$ & $7.1 \pm 0.2^{\mathrm{a}}$ & $7.1 \pm 0.2^{\mathrm{a}}$ & $7.1 \pm 0.2^{\mathrm{a}}$ \\
\hline day 8 & $7.4 \pm 0.2^{\mathrm{a}}$ & $7.4 \pm 0.2^{\mathrm{a}}$ & $7.4 \pm 0.3^{\mathrm{a}}$ & $7.5 \pm 0.2^{\mathrm{a}}$ & $7.7 \pm 0.2^{b}$ \\
\hline day 16 & $7.2 \pm 0.1^{\mathrm{a}}$ & $7.6 \pm 0.2^{\mathrm{b}}$ & $7.9 \pm 0.2^{\mathrm{b}}$ & $7.7 \pm 0.3^{b}$ & $7.7 \pm 0.2^{\mathrm{b}}$ \\
\hline day 24 & $7.7 \pm 0.2^{\mathrm{a}}$ & $7.7 \pm 0.3^{\mathrm{a}}$ & $8.0 \pm 0.4^{\mathrm{ab}}$ & $8.0 \pm 0.4^{\mathrm{ab}}$ & $8.2 \pm 0.2^{\mathrm{b}}$ \\
\hline day 32 & $7.9 \pm 0.2^{\mathrm{a}}$ & $8.1 \pm 0.3^{\mathrm{a}}$ & $7.8 \pm 0.2^{\mathrm{a}}$ & $8.1 \pm 0.3^{\mathrm{a}}$ & $8.2 \pm 0.2^{\mathrm{a}}$ \\
\hline \multicolumn{6}{|l|}{ Conductivity (mS cm-1) } \\
\hline day 1 & $29.2 \pm 0.4^{\mathrm{a}}$ & $29.2 \pm 0.4^{\mathrm{a}}$ & $29.2 \pm 0.4^{\mathrm{a}}$ & $29.2 \pm 0.4^{\mathrm{a}}$ & $29.2 \pm 0.4^{a}$ \\
\hline day 8 & $34.8 \pm 0.8^{a}$ & $35.5 \pm 0.8^{\mathrm{a}}$ & $34.2 \pm 0.5^{\mathrm{a}}$ & $34.9 \pm 0.7^{\mathrm{a}}$ & $34.2 \pm 1.5^{\mathrm{a}}$ \\
\hline day 16 & $33.1 \pm 1.2^{\mathrm{a}}$ & $34.3 \pm 1.0^{\mathrm{a}}$ & $34.0 \pm 1.9^{\mathrm{a}}$ & $33.1 \pm 0.8^{\mathrm{a}}$ & $33.7 \pm 0.6^{\mathrm{a}}$ \\
\hline day 24 & $29.8 \pm 2.3^{\mathrm{a}}$ & $30.9 \pm 1.9^{a}$ & $29.5 \pm 0.8^{a}$ & $30.6 \pm 1.8^{a}$ & $28.9 \pm 0.8^{a}$ \\
\hline day 32 & $31.4 \pm 1.6^{\mathrm{a}}$ & $31.7 \pm 1.8^{\mathrm{a}}$ & $31.7 \pm 3.5^{\mathrm{a}}$ & $30.3 \pm 1.8^{\mathrm{a}}$ & $28.9 \pm 2.6^{\mathrm{a}}$ \\
\hline \multicolumn{6}{|l|}{ Redox potential (mV) } \\
\hline day 1 & $-365 \pm 34^{\mathrm{a}}$ & $-365 \pm 34^{\mathrm{a}}$ & $-365 \pm 34^{\mathrm{a}}$ & $-365 \pm 34^{\mathrm{a}}$ & $-365 \pm 34^{\mathrm{a}}$ \\
\hline day 8 & $-392 \pm 72^{\mathrm{a}}$ & $-393 \pm 54^{\mathrm{a}}$ & $-388 \pm 88^{a}$ & $-392 \pm 62^{\mathrm{a}}$ & $-391 \pm 32^{\mathrm{a}}$ \\
\hline day 16 & $-396 \pm 76^{a}$ & $-385 \pm 34^{a}$ & $-377 \pm 44^{\mathrm{a}}$ & $-405 \pm 35^{\mathrm{a}}$ & $-409 \pm 51^{a}$ \\
\hline day 24 & $-413 \pm 58^{a}$ & $-397 \pm 88^{a}$ & $-337 \pm 58^{\mathrm{a}}$ & $-422 \pm 45^{\mathrm{a}}$ & $-431 \pm 43^{\mathrm{a}}$ \\
\hline day 32 & $-419 \pm 37^{b}$ & $-395 \pm 67^{\mathrm{b}}$ & $-133 \pm 76^{a}$ & $-428 \pm 35^{b}$ & $-442 \pm 47^{b}$ \\
\hline \multicolumn{6}{|l|}{ Ammonia (mol L-1) } \\
\hline day 1 & $0.59 \pm 0.10^{\mathrm{a}}$ & $0.59 \pm 0.10^{\mathrm{a}}$ & $0.59 \pm 0.10^{\mathrm{a}}$ & $0.59 \pm 0.10^{a}$ & $0.59 \pm 0.10^{\mathrm{a}}$ \\
\hline day 8 & $0.49 \pm 0.10^{\mathrm{a}}$ & $0.46 \pm 0.07^{\mathrm{a}}$ & $0.46 \pm 0.12^{\mathrm{a}}$ & $0.45 \pm 0.12^{\mathrm{a}}$ & $0.45 \pm 0.10^{\mathrm{a}}$ \\
\hline day 16 & $0.45 \pm 0.12^{\mathrm{a}}$ & $0.45 \pm 0.10^{\mathrm{a}}$ & $0.44 \pm 0.12^{\mathrm{a}}$ & $0.40 \pm 0.10^{\mathrm{a}}$ & $0.42 \pm 0.10^{\mathrm{a}}$ \\
\hline day 24 & $0.41 \pm 0.20^{\mathrm{a}}$ & $0.45 \pm 0.11^{\mathrm{a}}$ & $0.43 \pm 0.14^{\mathrm{a}}$ & $0.40 \pm 0.18^{a}$ & $0.41 \pm 0.12^{\mathrm{a}}$ \\
\hline day 32 & $0.41 \pm 0.30^{\mathrm{a}}$ & $0.44 \pm 0.23^{\mathrm{a}}$ & $0.37 \pm 0.11^{\mathrm{a}}$ & $0.37 \pm 0.12^{\mathrm{a}}$ & $0.36 \pm 0.10^{\mathrm{a}}$ \\
\hline
\end{tabular}

a,bDifferent letters show significant statistical difference between treatments (Kruskal-Wallis test, $\mathrm{P}<0.05$ ).

Table 2. Effect of electrolytic treatment of swine slurry on emission rates and cumulated emissions of hydrogen sulphide and methane. Values are mean of three independent replicates \pm standard deviation. Different letters show significant statistical difference between treatments (Kruskal-Wallis test, $\mathbf{P}<0.05)$.

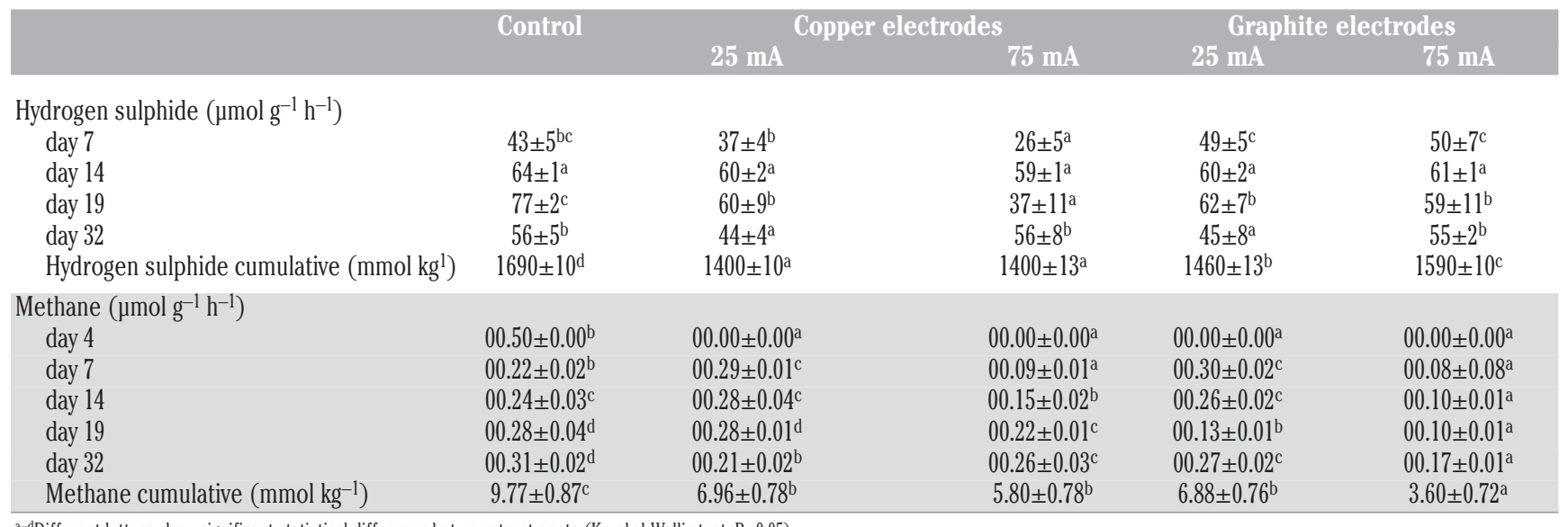

${ }^{\mathrm{a}-\mathrm{d} D i f f e r e n t}$ letters show significant statistical difference between treatments (Kruskal-Wallis test, $\mathrm{P}<0.05$ ). 
of acetic acid were low at the first sampling, then they increased after 19 days, to decrease again at the last sampling (Figure 1). For each VFA, a cumulative sum of emissions was calculated after the 32 days, results are reported in Figure 2. The number of measures during the 32 days might not have been sufficient to state the dynamics of acidic emissions; however, the aim of this work was not to monitor emission trends, but to highlight differences among treatments. Timing of measures was chosen on the basis of preliminary experiments. At the intensity of $25 \mathrm{~mA}$, no meaningful difference in cumulative emissions of VFAs was found with respect
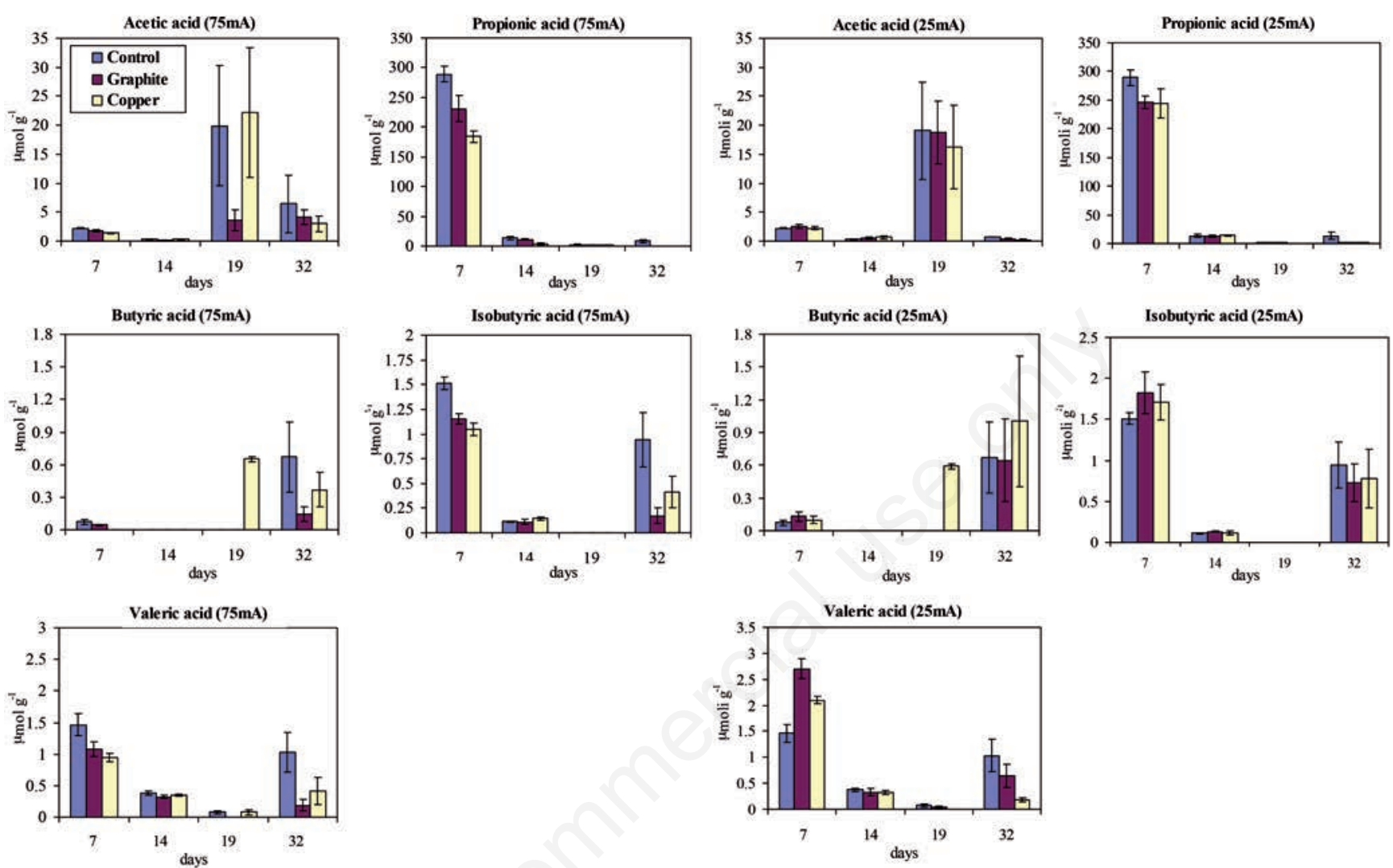

Figure 1. Emissions of volatile fatty acids in $\mu$ moles per gram of swine slurry during the experiment. Slurries were electrolytically treated at $25 \mathrm{~mA}$ (right) and $75 \mathrm{~mA}$ (left). Error bars represent standard deviation.
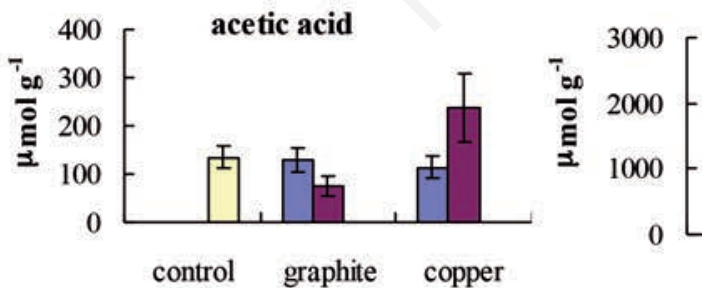

propionic acid

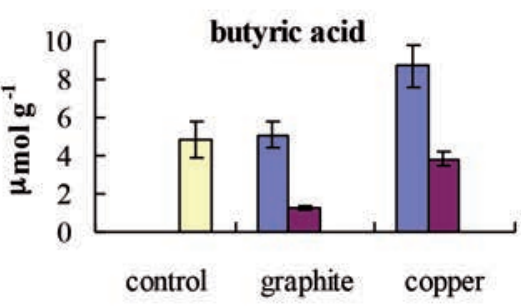

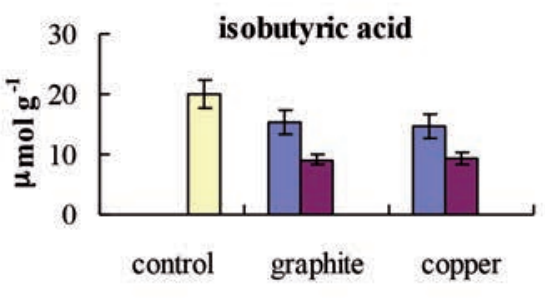

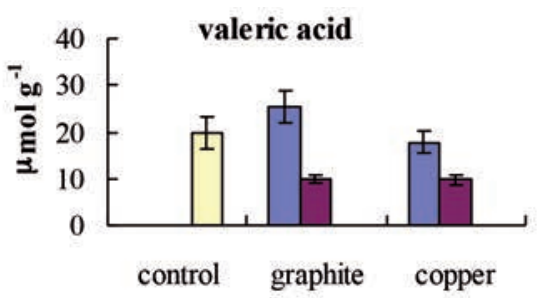

$\square 25 \mathrm{~mA}$

$75 \mathrm{~mA}$

$\square$ control

Figure 2. Cumulated emissions of volatile fatty acids from swine slurries treated at $25 \mathrm{~mA}$ and $75 \mathrm{~mA}$. Values are expressed in $\mu \mathrm{moles}$ per gram of slurry. Error bars represent standard deviation. 
to the control, most likely due to the high variability of the replicates. Evidently, current intensity was too low to affect the system, with the only exception of propionic acid emissions, which decreased due to the electrolytic treatment. On the contrary, reduction of VFA emissions was significant for the $75 \mathrm{~mA}$ intensity treatments and differences between graphite and copper electrodes increased. The only exception of emissions was acetic and butyric acids in the treatment with copper electrodes (Figures 1 and 2).

The $75 \mathrm{~mA}$ intensity electrolytic treatment with graphite electrodes reduced the value of OI by about $25 \%$ with respect to the control, whereas, that with copper electrodes by about $40 \%$. The $25 \mathrm{~mA}$ intensity treatment reduced it of only about $15 \%$ with both graphite and copper electrodes (Figure 3).

\section{Effect of copper addition treatment on emissions}

Emissions of VFA were reduced with favourable proportionality to the amount of copper added with the only exception of the slurry treated with $400 \mathrm{mg} \mathrm{Cu}{ }^{2+} \mathrm{kg}^{-1} \mathrm{TS}$ where emission of acetic acid was larger than the control (Figure 4).

Addition of $\mathrm{Cu}^{2+}$ ions did not result in inhibition of methane production at the lower addition rates: emissions were even larger than in the control with 400 and $800 \mathrm{mg} \mathrm{Cu}^{2+} \mathrm{kg}^{-1}$ TS (Figure 5) but decreased at $1200 \mathrm{mg} \mathrm{Cu}^{2+} \mathrm{kg}^{-1}$. On the contrary, hydrogen sulphide emissions were considerably reduced even at a rate of 200 $\mathrm{mg} \mathrm{Cu}{ }^{2+} \mathrm{kg}^{-1} \mathrm{TS}$, without differences among copper addition rates (Figure 5).

The OI index revealed that copper additions were effective even at the lowest rate in reducing the potential noxious odour impact of the treated slurries (Figure 6).

\section{Discussion}

Our results confirmed that the release of foul smelling volatile substances from swine slurry could be reduced by applying electrolytic treatments of sufficient intensity. The highest intensity treatment at $75 \mathrm{~mA}$, was within the optimum current intensity interval proposed by Skjelhaugen and Donantoni (1988) and resulted in the strong reduction of the amounts of propionic acid, butyric acid, isobutyric acid, and valeric acid emitted by a

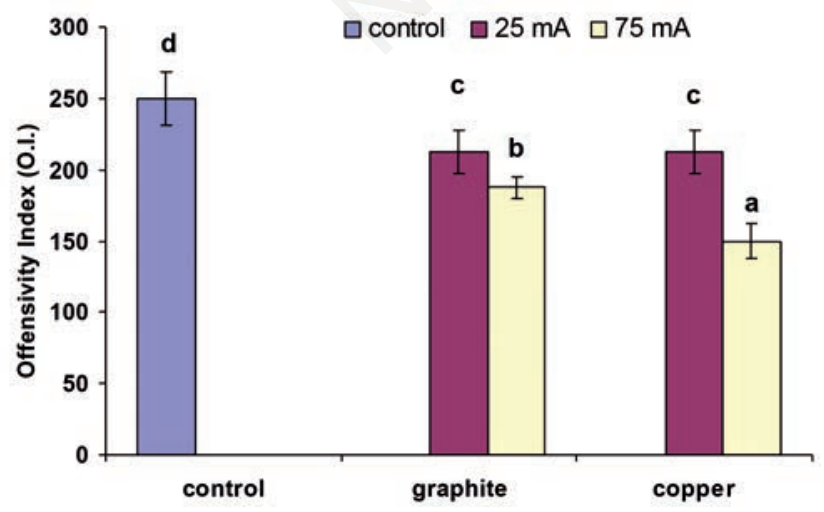

Figure 3. Odour offensivity index values calculated at the end of the experiment for slurries treated at $25 \mathrm{~mA}$ and $75 \mathrm{~mA}$. Error bars represent standard error of the mean. Different letters show significant statistical difference between treatments (KruskalWallis test, $\mathrm{P}<0.05$ ).
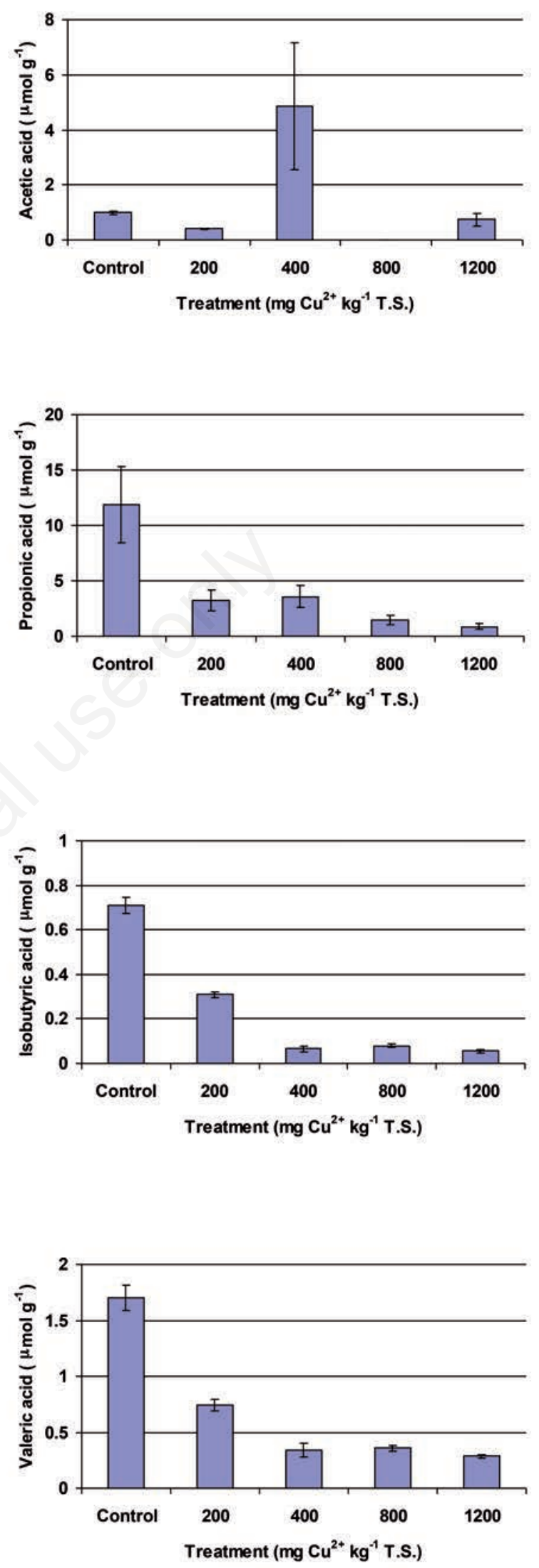

Figure 4. Cumulated emissions ( $\mu$ mol per gram) of volatile fatty acids in swine slurry after 7 days from addition of $\mathrm{CuCl}_{2}$. The amount of copper added $\left(\mathrm{mg} \mathrm{C \textrm {C } ^ { 2 + }}\right)$ is referred per $\mathrm{kg}$ of total solids (T.S.). Error bars represent standard error of the mean. 
unit (mass) of slurry (Figure 2). The $25 \mathrm{~mA}$ treatment, which was the minimum current intensity outside the suggested range that would result in a potential difference that allowed the dissolution of copper, still demonstrated that VFA production was abated by current application at suboptimal level. Acetic acid emissions were, in all cases, very variable and copper dissolution from electrodes even appeared to promote acetic acid emission, as was in fact confirmed by the experiment with copper addition. The experiment with direct copper addition also proved that hydrogen sulphide emissions could be indeed reduced due to formation of insoluble copper sulphides and microorganism inhibition with no need of any electric current treatment.

The oxidation-reduction potentials measured indicated a relatively lower intensity of fermentation processes with respect to the control, but not so drastic, as to point out a real inhibition of anaerobes, except for the $75 \mathrm{~mA}$ intensity treatment with copper electrodes. The change in redox potential observed in this treatment indicated that anaerobic microbial metabolism was impaired by copper ions, because a current of the same intensity had no effect if applied with graphite electrodes. The increase in the redox potential is an adequate indicator of reduced activity of anaerobes, but it is not sufficient to demonstrate foul odour reduction in slurry. However, the lower methane emissions produced by electric current passage in the $75 \mathrm{~mA}$ treatments, also confirmed the reduction of fermentation intensity. This is coherent with results obtained for VFA, which are the main substrate for methanogenic bacteria (Montero et al., 2010; Orzi et al., 2010). It is difficult to explain why, for acetic acid, emissions seemed to be increased by electrolytic treatments. The most likely explanation is in the complex microbial community operating
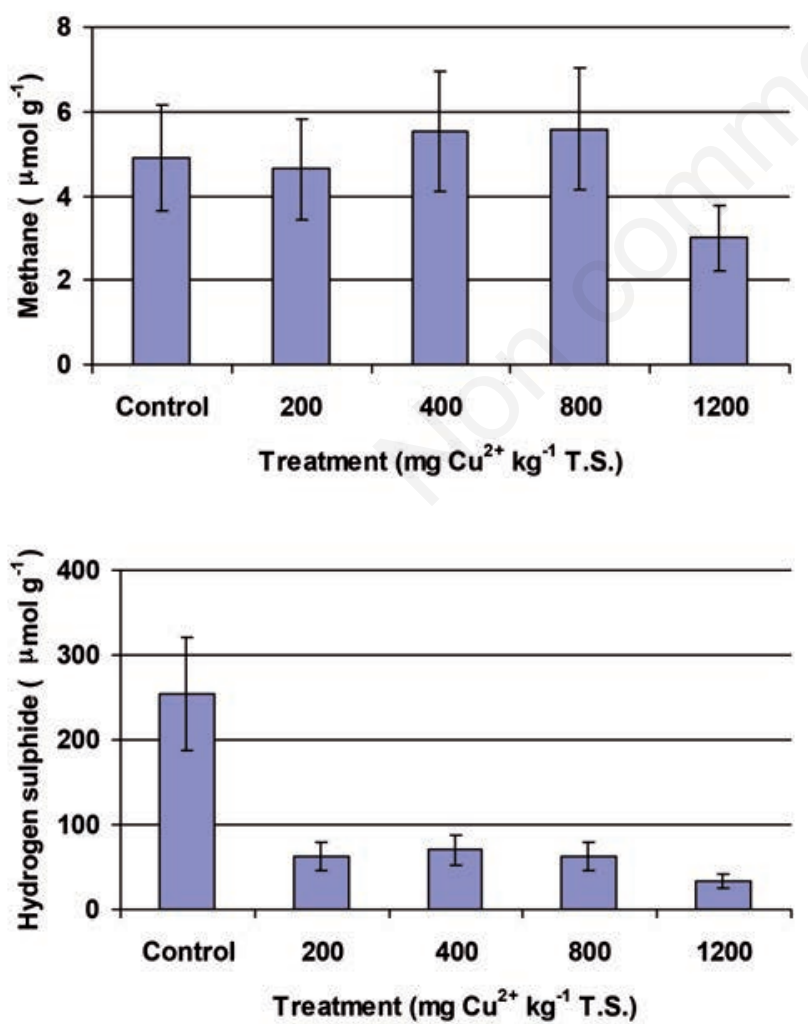

Figure 5. Emissions of methane and hydrogen sulphide in $\mu \mathrm{mol}$ per gram of slurry, 7 days after addition of $\mathrm{CuCl}_{2}$, the amount of copper is referred to the weight of total solids (T.S.) in the slurry. Error bars represent standard error of the mean. in the slurry; death or stress conditions may not only impair the growth of some types of microorganisms and cause accumulation of intermediate decomposition products, but may also promote the activity of others. Therefore, these data should correspond to the death or growth of a particular strain or family of microorganisms. The dynamics of acetic acid are very interesting due to low emissions at the beginning of the experiment, that increase after 19 days, and then to decrease again, and are apparently stimulated by copper ions.

The superior efficiency in reducing foul emissions of copper electrodes as compared to graphite electrodes is evidently due to copper dissolution as confirmed by the $\mathrm{Cu}^{2+}$ addition experiment. Figure 6 shows the effect of treatment with copper ions through an odour index calculated from the sum of the cumulated concentration of each volatile fatty acid normalised by its relative OTV. Human odour perception may be based on compounds that are not detected by chromatographic analysis or be affected by synergic effects between different organic molecules (Gralapp et al., 2001). Hence, it is very difficult to predict on the basis of chemical analysis. Normalisation of emissions by OTV, such as in the OI of slurries that has been devised for this work, can provide a realistic evaluation of potential impacts. Similar approaches have been proved useful in the evaluation of the toxicity of mixtures of compounds, such as dioxins (EPA, 2008) and are much more simple, economic, and straightforward in their application than panel-based sensory tests. This simple empiric offensivity index calculated from OTV normalised concentrations was able to differentiate among the different treatments and showed a significant reduction of potential offensiveness with electrolytic treatment at $75 \mathrm{~mA}$ intensity. The index also demonstrated an effect of the use of copper electrodes but the difference was not statistically significant. Direct addition of copper ions had a more profound effect (Figure 6). A further standardisation against panel tests is, however, undoubtedly needed to fully validate its application, but our results indicate that it would represent a useful tool for routine monitoring operations or for pre-screening of the effectiveness of measures taken for the abatement of odors.

The amount of copper theoretically dissolved during the 25 $\mathrm{mA}$ electrolytic treatment with copper electrodes after 32 days

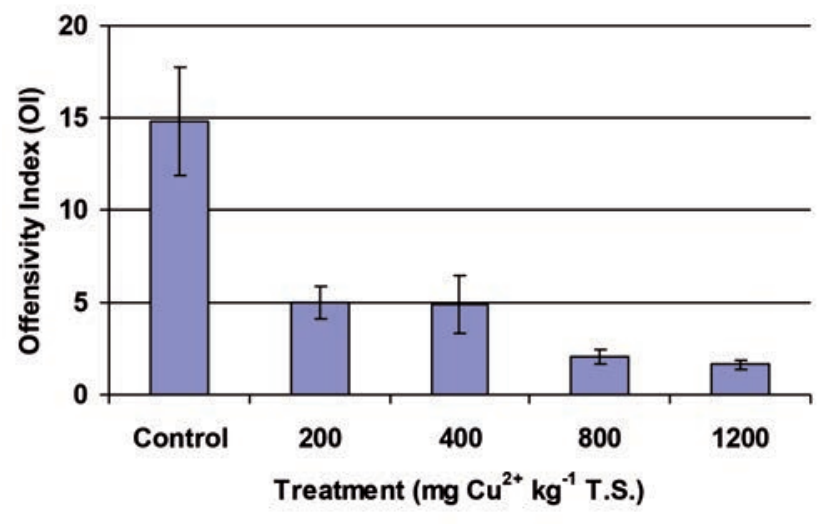

Figure 6. Odour offensivity index values (OI) of $\mathrm{CuCl}_{2}$ treated slurries after 7 days from the treatment. $\mathrm{OI}$ is calculated as the sum of the emissions of volatile fatty acids, each divided by its odour threshold value, the amount of copper added $\left(\mathrm{mg} \mathrm{Cu}^{2}+\right)$ is referred to the weight of total solids (T.S.). Error bars represent standard error of the mean. 
corresponded to about $200 \mathrm{mg} \mathrm{Cu}{ }^{2+} \mathrm{kg}^{-1}$ T.S. and that at $75 \mathrm{~mA}$ to about $600 \mathrm{mg} \mathrm{Cu}{ }^{2+} \mathrm{kg}^{-1}$ T.S. Therefore, direct additions of $\mathrm{Cu}^{2+}$ ions had a much larger effect than could be predicted from the results of electrolytic treatments with copper electrodes. In fact, in a similar experiment, conducted on a larger scale and at stronger current intensity ( $600 \mathrm{~L}$ and $200 \mathrm{~mA}$ ), the concentrations of copper measured in the liquid phase and suspended solids of the control, were respectively $1.39 \pm 0.03 \mathrm{mg} \mathrm{L}^{-1}$ and $31.3 \pm 0.3 \mathrm{mg}$ $\mathrm{kg}^{-1}$, that of the graphite electrodes treatment, were and $1.17 \pm 0.03 \mathrm{mg} / \mathrm{L}$ and $26.83 \pm 0.18$, whereas, those in the copper electrodes treatment were $1.16 \pm 0.02 \mathrm{mg} / \mathrm{L}$ and $32.8 \pm 0.4 \mathrm{mg} / \mathrm{kg}$. Evidently, much of the copper dissolved at the anode precipitated during the experiment due to the alkaline $\mathrm{pH}$ of the slurries (Table 1) and to $\mathrm{CuS}$ formation, so that availability of $\mathrm{Cu}^{2+}$ ions to microorganisms was greatly reduced.

Electrochemical treatments reduced gas emission also at pilot scale (i.e., volume $650 \mathrm{~L}$, copper and graphite electrodes, 0.2-1.0 A current intensity, 1-4 min polarity inversion times) (Da Borso et al., 2002). To correctly scale up the technology, other aspects should be more thoroughly investigated, for example, the difficulty of achieving adequate homogeneity of treatment in large volume tanks and the requirement of higher current intensities than in standard commercial systems (reverse time of $10 \mathrm{~min}$ and an intensity of current of 0.5 and $1 \mathrm{~A}$ ).

\section{Conclusions}

Our results showed that electrolytic treatments do not have a strong influence on the amount of methane, hydrogen sulphide, or ammonia, but they primarily affect VFA emissions. The process can be implemented at full scale only after performing a suitable correction of electrochemical parameters. This work, however, improves our understanding of affecting factors. The OI proposed in this paper, allowed for differentiation among different treatments and showed reduced potential offensivity in the case of higher current application. The effect was only slightly increased by copper dissolution, when the current was applied with copper electrodes, however, copper ions alone, when added as a single addition of $\mathrm{CuCl}_{2}$ markedly reduced VFA and hydrogen sulphide emissions even at a rate lower than that theoretically released by the $25 \mathrm{~mA}$ current treatment. The action of electrolytic treatments, therefore, differed from that of a simple bacteriostatic action exerted by copper ions, as they cannot reach the necessary solution concentrations. The proposed tentative OTV normalised potential offensivity index was found to be very effective in differentiating the effect of the treatments on odorous compounds suppression and, after validation with sensory (olfactometry) tests, could offer an easily determined and sensitive parameter for routine monitoring of outdoor air quality near pig farms and after slurry distribution.

\section{References}

APHA, AWWA, WPCF, 1992. Standard methods for the examination of water and wastewater. 18th ed. Washington, DC, USA.

Barth C.L., Hill O.T., Polkowski L.B. 1974. Correlating odour intensity index and odorous components in stored dairy manure. Trans. Am. Soc. Agric. Eng. 17:742:7.

Bejan D., Rabson L., Bunce N. 2007. Electrochemical deodoriza- tion and disinfection of hog manure. Can. J. Chem. Eng. 85:929-35.

Bejan D., Sagitova F., Bunce N.J. 2005. Evaluation of electrolysis for oxidative deodorization of hog manure. J. Appl. Electrochem. 35:897-902.

Chiumenti R., Da Borso F., Guercini S. 1993. Guida tecnica per la gestione delle deiezioni zootecniche. Provincia di Padova, Assessorato Tutela Ambiente, Assessorato all'Agricoltura ed., Padova, Italy.

Chiumenti R., Donantoni L. 1991. Study of the electrolytic treatment applied to livestock manure at pilot scale plant. Proc. CIGR Seminar on Environmental challenges and solutions in agricultural engineering, Aas, Norway.

Chiumenti R., Donantoni L., Guercini S. 1988. Il controllo degli odori nei liquami zootecnici. Genio Rurale 5:33-41.

Da Borso F., Rodar T., Mezzadri M., Chiumenti A., Chiumenti R. 2002. Control of gaseous emissions from stored pig slurry by means of electrochemical treatment. Proc. 10th Conference Hygiene Safety RAMIRAN, Strbske Pleso, Slovak Republic.

EPA (U.S. Environmental Protection Agency). 2008. EPA/100/R$08 / 004$. Framework for application of the toxicity equivalence methodology for polychlorinated dioxins, furans, and biphenyls in ecological risk assessment. U.S. Environmental Protection Agency, Washington, DC, USA. Available from: http://www.epa.gov/sites/production/files/2013-09/documents/tefs-draft-052808-0804.pdf Accessed: November 2016.

Gralapp A.K., Powers W.J., Bundy, D.S. 2001. Comparison of olfactometry, gas chromatography, and electronic nose technology for measurement of indoor air from swine facilities. Swine Research Report, 2000.28. Available from: http://lib.dr.iastate.edu/swinereports_2000/28 Accessed: November 2016.

Hanajima D., Kuroda K., Morishita K., Fujita J., Maeda K., Morioka R. 2010. Key odor components responsible for the impact on olfactory sense during swine feces composting. Bioresour. Technol. 101:2306-23.

Higgins M.J., Adams G., Chen Y.C., Erdal Z., Forbes Jr. R.H., Glindemann D., Hargreaves J.R., McEwen D., Murthy S.N., Novak J.T., Witherspoon J. 2008. Role of protein, amino acids, and enzyme activity on odor production from anaerobically digested and dewatered biosolids. Water Environ. Res. 80:127-35.

Jones K.B.C. 1977. UK problems and legislation relating to odour control. Agric. Environ. 3:245-58.

Leek A.B.G., Hayes E.T., Curran T.P., Callan J., Beattie V.E., Dodd V.A., O'Doherty J.V. 2007. The influence of manure composition on emissions of odour and ammonia from finishing pigs fed different concentrations of dietary crude protein. Bioresour. Technol. 98:3431-9.

Lovley D.R. 2008. The microbe electric: conversion of organic matter to electricity. Curr. Opin. Biotechnol. 19:564:71.

Montero B., Garcia-Morales J.L., Sales D., Solera R. 2010. Evolution of butyric acid and the methanogenic microbial population in a thermophilic dry anaerobic reactor. Waste Manage. 30:1790-7.

Orzi V., Cadena E., D’Imporzano G., Artola A., Davoli E., Crivelli M., Adani F. 2010. Potential odour emission measurement in organic fraction of municipal solid waste during anaerobic digestion: relationship with process and biological stability parameters. Bioresour. Technol. 101:7330-7.

Persaud K.C., Khaffaf S.M., Hobbs P.J., Sneath R.W. 1996. Assessment of conducting polymer odour sensors for agricultural malodour measurements. Chem. Senses. 21:495-505.

Ranalli G., Chiumenti R., Donantoni L., Sorlini C. 1996. 
Electrolytic treatment of swine liquid manure in a full scale experiment. J. Environ. Sci. Health. 31:1705-21.

R Development Core Team. 2010. R: a language and environment for statistical computing. Wien, Austria. Available from: http://www.R-project.org Accessed: August 2010.

Rappert S., Müller R. 2005. Odor compounds in waste gas emissions from agricultural operations and food industries. Waste Manage. 25:887-907.

Rosenbaum M., Aulenta F., Villano M., Angenent L. 2010. Cathodes as electron donors for microbial metabolism: Which extracellular electron transfer mechanisms are involved? Bioresour. Technol. 102:324-33.

Ruth J.H. 1986. Odor thresholds and irritation levels of several chemical substances: a review. Am. Ind. Hyg. Assoc. J. 47:143-51.

Sheridan B.A., Curran T.P., Dodd V.A. 2003. Biofiltration of nbutyric acid for the control of odour. Bioresour. Technol. 199:205-89.

Shigeta Y. 1976. Odour pollution and deodorization techniques. pp 386-424 in IPC Kogai Boshi Ken Kyukai, Tokyo, Japan.

Shusterman D. 1992. Critical review: the health significance of environmental odor pollution. Arch. Environ. Health 47:76-87.

Skjelhaugen O.J., Donantoni L. 1988. Combined aerobic and elec- trolytic treatment of cattle slurry. J. Agric. Eng. Res. 70:209-19.

Spolestra S.F. 1979. Volatile fatty acids in anaerobically stored piggery wastes. Neth. J. Agric. Sci. 27:60-6.

Spolestra S.F. 1980. Origin of objectionable odorous components in piggery wastes and the possibility of applying indicator components for studying odour development. Agric. Environ. 265:241-60.

Varel V.H., Miller D.N. 2001. Effect of carvacrol and thymol on odour emissions from livestock wastes. Water Sci. Tech. 44:143:8.

Yasuhara A., Fuwa K., Jimbu M. 1984. Identification of odorous compounds in fresh and rotten swine manure. Agric. Biol. Chem. 48:111.

Zanardini E., Valle A., Gigliotti C., Pagano G., Ranalli G., Sorlini C. 2002. Laboratory-scale trials of electrolytic treatment on industrial wastewater: microbiological aspects. J. Environ. Sci. Health 8:1463-81.

Zhu J. 2000. A review of microbiology in swine manure odour control. Agric. Ecosyst. Environ. 78:93-106.

Zhu J., Riskowski G.L., Torremorell M. 1999. Volatile fatty acids as odor indicators in swine manure - A critical review. Trans. ASAE 42:175-82. 